\title{
HAND2 wt Allele
}

National Cancer Institute

\section{Source}

National Cancer Institute. HAND2 wt Allele. NCI Thesaurus. Code C102791.

Human HAND2 wild-type allele is located in the vicinity of $4 \mathrm{q} 33$ and is approximately $5 \mathrm{~kb}$ in length. This allele, which encodes heart- and neural crest derivatives-expressed protein 2 , is involved in cardiac morphogenesis, DNA binding and transcriptional modulation. 